\title{
GAS-CHROMATOGRAPHY ASSESSMENTS OF THE MAJOR VOLATILE COMPOUNDS IN TRADITIONAL FRUIT BRANDIES THROUGHOUT FRUIT AND WOOD MATURATION.
}

\section{THOMAS DIPPONG ${ }^{a}$, ALEXANDRA AVRAM $^{\mathrm{b}, *}$, CRISTINA MIHALI $^{\mathrm{a}}$}

\begin{abstract}
Traditional home-made plum and apple brandies were analysed aiming to assess the main physico-chemical characteristics including density, ethanol content, total acidity, total extract, total sulphur dioxide $\left(\mathrm{SO}_{2}\right)$ and refractive indices. The major volatile compounds, such as, methanol, linear superior alcohols (propan-1-ol, butan-1-ol, butan-2-ol), branched superior alcohols (2-methylpropan-1-ol and 3-methylbutan-1-ol) and also ethyl acetate, acetaldehyde and acetal compounds, were assessed using gas chromatography coupled with flame ionization detector (GC-FID). The technology of incorporating fruit (cherries and pears) or wood (mulberry and poplar) in the brandy was presented along with the influence of their addition on the composition of the plum and apple brandies and on their physico-chemical characteristics. The changes in the composition of plum and apple brandies throughout 4 weeks of maturation process in the presence of wood or fruit, showed an increase in density, acidity and total extract and decrease in the concentration of ethanol, total sulphur dioxide $\left(\mathrm{SO}_{2}\right)$ and acetaldehydes. The addition of mulberry and poplar wood in the brandies decreased the concentration of acetaldehyde. The addition of both fruits significantly increased the concentration of ethyl acetate.
\end{abstract}

Keywords: volatile substances, gas chromatography, wood embedding, fruit embedding

a Department of Chemistry and Biology, Faculty of Sciences, Technical University of ClujNapoca, Victoriei Street 76, 430122 Baia Mare, Romania

b Faculty of Chemistry and Chemical Engineering, Babeş-Bolyai University, Arany Janos Street. 11, RO-400028, Cluj-Napoca, Romania

* Corresponding author: aavram@chem.ubbcluj.ro 


\section{INTRODUCTION}

Plum brandy ("tuica, palinka") is an alcoholic beverage obtained by the fermentation followed by distillation of plum marc without kernels, following a special technological process. Quality plum brandy has the specific taste and perfume of the fruit, flavours, obtained from the correct application of the crushing and fermentation processes, plus the features gained from maturing and aging [1]. The quality of brandy is influenced by several factors: soil and climate characteristics, plum varieties and the technological aspects of the manufacturing process $[2,3]$. Plum distillates are highly complex mixtures (higher alcohols, acids, esters, carbonyl compounds), contained in an ethanolwater mixture $[4,5,6]$. Plum brandy may also contain methyl alcohol resulting from the decomposition of pectin [2] similar to several other alcoholic beverages derived from fermented fruit $[7,8]$. The presence of this toxic substance in distillates is carefully monitored and supervised by the concerned authorities [1,9]. The intake may become higher in the presence of ethyl alcohol, which is the antidote of methanol poisoning [7]. The methanol content of the alcoholic beverages derived from fermented fruit may be used to evaluate their authenticity and natural fruit origin [6].

Acetaldehyde is the most volatile substance in distilled alcoholic beverages, formed during fermentation and is considered the main compound resulting from the biochemical reaction of yeast acetic acid bacteria coupled with the self-oxidation of ethanol and phenolic compounds [10,11, 12]. The acetal is formed during distillation, at elevated temperatures, and at high ethanol levels. Concentrations of acetaldehyde are dependent on fermentation conditions, temperature, $\mathrm{pH}, \mathrm{O}_{2}$ and $\mathrm{SO}_{2}$ levels and the availability of nutrients from yeast $[11,12]$. Formation of acetaldehyde is favoured by the storage of raw materials under anaerobic conditions [13]. Low concentrations of acetaldehyde give pleasant fruit flavours, while high concentrations can lead to irritating odours. Higher alcohols have a significant impact on the flavour of the brandy range, but also on the toxicity [14]. Also called fusel oils, they have a higher boiling point than ethanol, present a strong aroma and can be recovered depending on the raw materials and yeasts used for fermentation [10].

Apple brandy is an alcoholic beverage obtained through the distillation of fermented mashes of ripe apples. Fruit brandies are often stored for maturation in wood barrels (oak, mulberry, poplar or chesnut). During the maturation period, the beverage acquires interesting sensorial characteristics, as a result of extraction and degradation of many compounds from the wood matrix [15].

The analysis of fruit brandy (spirit) manufactured by traditional methods in European countries was the subject of several papers [4,5,16]. The analysis of these types of beverages has a significant importance in the authentication, control and prevention of fraud [16]. However, the details regarding the 
manufacturing stages are less described. A thorough documentation on the home-made traditional fruit brandy in the Maramures area was performed. The distillate contains 3 parts: "forehead", "middle" and "tail". The forehead represents $1.5-2 \%$ of the distillate, with $70-72 \%$ alcohol with a large amount of methyl alcohol. The tail has a very low alcoholic content and sour taste. The middle (main distillate) represents $40-50 \%$ of the total distillate. Distillation stops when the tail has an alcohol content of below $15 \%$. The forehead and tail are collected separately and added to the next decoction for distillation. First distillation produces brandy (30-35\% alcohol) with an ambiguous taste. During the second distillation, the content of the most volatile component is reduced. Aging is usually completed in wood barrels, in which the brandy turns dark, yellow-brown and of harmonious taste.

The wood embedding technique consists in the insertion of handcraft objects made of poplar or mulberry wood, into the brandy bottles. In regards to the fruit embedding technique, the fruit is not only decorative; it imparts to the drink its color, aroma and special properties. It contains vitamins and minerals that get transmitted into the beverage. Once sealed, the bottle can be kept for decades.

The aims of the study were: (i) to present the traditional manufacturing process of fruit brandy production which is part of the gastronomic heritage from Maramures County (NW of Romania) (ii) to investigate the composition of different fruit brandies, (iii) to depict the changes that took place as a consequence of embedding wood or fruit in the fruit brandy. Physicochemical analysis of the brandy samples, including the gas chromatography analysis of volatile compounds were performed. The changes in physicochemical characteristics of brandies throughout 4 weeks maturation, when the product was kept in contact with wood or fruit, were investigated.

\section{RESULTS AND DISCUSSIONS}

\section{Physico-chemical analysis of brandy assortments}

Table 1 presents the physico-chemical determinations of four samples of fruit brandy: plum brandy (PB1), plum brandy with mulberry wood (PBM), AB (apple brandy), ABP (apple brandy with poplar wood).

The results shown in Table 1 indicate that the addition of wood to brandy have a significant influence on the following parameters: density, ethanol concentration, total acidity, total $\mathrm{SO}_{2}$ and aldehyde content of the brandies and a less significant influence on the total extract of the beverages. The refractive index of the beverages showed only a slight variation. In the case of most of parameters, the influence was significant after 2 or 3 weeks. 
Table 1. Physico-chemical properties of PB1, PBM, AB, ABP fruit brandy samples and their evolution during four weeks of preservation in contact with wood

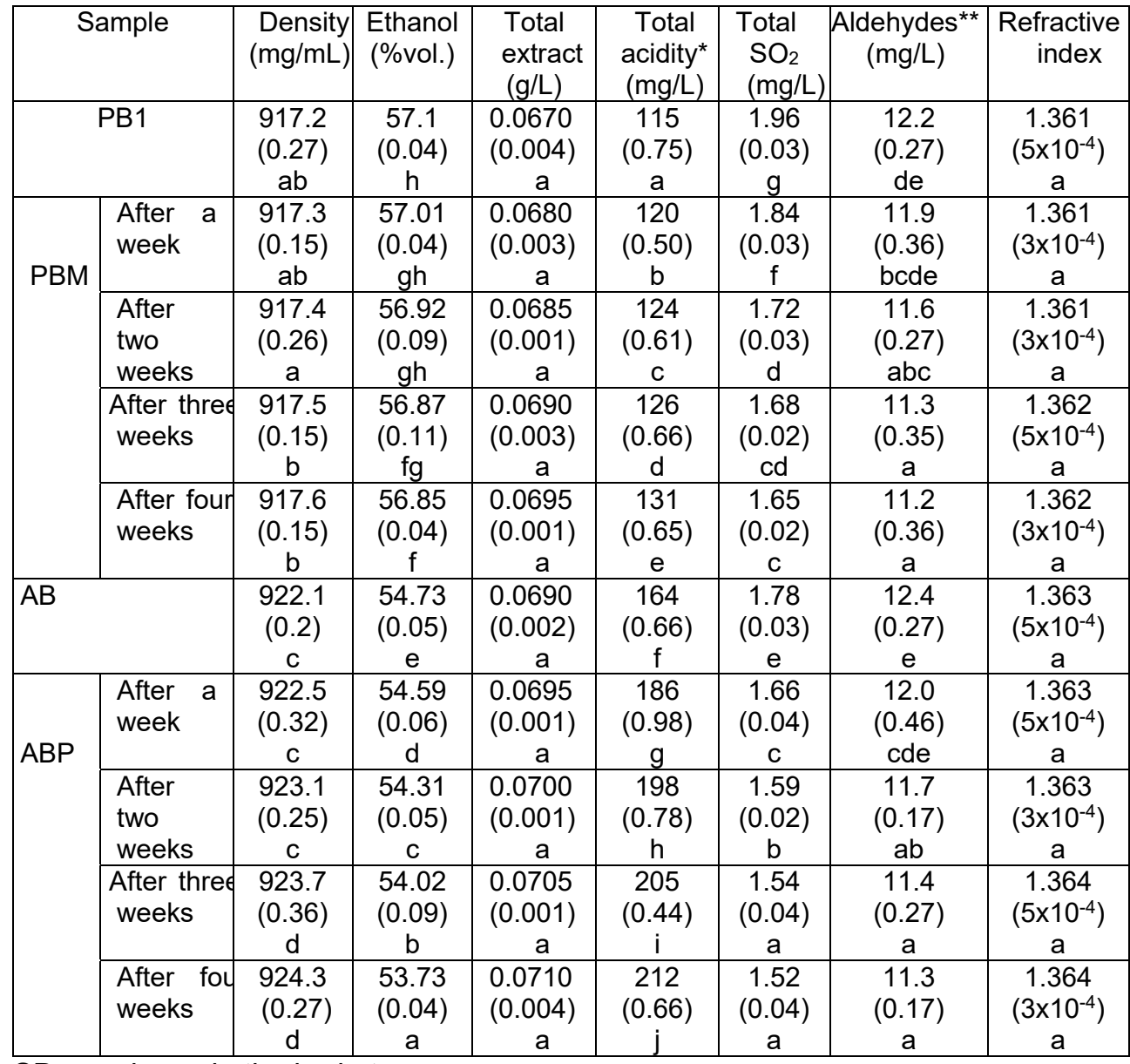

SD are shown in the brakets

* expressed as acetic acid; ${ }^{* *}$ expressed as acetaldehyde

The values with different letters in a column ( $a, b, c$ etc.) are significantly different at $\mathrm{P}<0.05$

It was found that the plum brandy density, acidity and total extract increased after the addition of mulberry wood, after the first week. Regarding the ethanol content, total $\mathrm{SO}_{2}$ and aldehydes, they decreased over time. The density, acidity and extract of apple brandy increased even after one week of adding poplar wood. The alcohol losses of samples were due to both evaporation and changes that alcohol suffered over time. Part of the ethanol forms chemical combinations with acids and oxygen in air to form acetaldehydes, ethers. The 
increase in total extract was recorded due to the transformations suffered by distillates over time. The increase in acidity was due to the presence of soluble acids in the composition of the two types of wood, and, especially the very slow oxidation of alcohol in acetic acid. After comparing the refractive indices, a slight increase was observed both for PB1 and PBM due to the dissolving and evaporation processes that occurred during storage.

Table 2 presents the physico-chemical properties in order to trace the fruit effect on the quality of the brandy: plum brandy (PB2), plum brandy maturated with cherry (PBC) and plum brandy maturated with pear (PBP). The fruit to brandy additions have a significant influence on the all the investigated parameters. The influence was significant after the first week of treatment except ethanol concentration of PBC brandy that showed a decrease after four weeks of maturation.

Table 2. Physico-chemical properties of PB2, PBC, PBP fruit brandy samples and their evolution during four weeks of preservation in contact with fruit

\begin{tabular}{|c|c|c|c|c|c|c|c|c|}
\hline & Sample & $\begin{array}{l}\text { Density } \\
(\mathrm{mg} / \mathrm{mL})\end{array}$ & $\begin{array}{l}\text { Ethanol } \\
\text { (\%vol.) }\end{array}$ & $\begin{array}{c}\text { Total } \\
\text { extract } \\
(\mathrm{g} / \mathrm{L})\end{array}$ & $\begin{array}{c}\text { Total } \\
\text { acidity } \\
\text { (mg/L) }\end{array}$ & $\begin{array}{c}\text { Total SO } \\
(\mathrm{mg} / \mathrm{L})\end{array}$ & $\begin{array}{c}\text { Aldehydes* } \\
\text { (mg/L) }\end{array}$ & ndice \\
\hline PB2 & & $\begin{array}{c}932.0 \\
(0.46) \\
a\end{array}$ & $\begin{array}{c}55.45 \\
(0.09) \\
c\end{array}$ & $\begin{array}{c}0.0670 \\
(0.001) \\
a\end{array}$ & $\begin{array}{c}117 \\
(0.50) \\
a\end{array}$ & $\begin{array}{c}1.96 \\
(0.01) \\
\mathrm{e}\end{array}$ & $\begin{array}{c}4.40 \\
(0.1) \\
\mathrm{h}\end{array}$ & $\begin{array}{c}1.363 \\
\left(3 \times 10^{-4}\right) \\
a\end{array}$ \\
\hline \multirow[t]{4}{*}{ PBC } & fter a wee & $\begin{array}{c}932,9 \\
(0.61) \\
b\end{array}$ & $\begin{array}{c}55.41 \\
(0.08) \\
c\end{array}$ & $\begin{array}{c}0.0677 \\
(0.0015) \\
a b\end{array}$ & $\begin{array}{c}124 \\
(0.87) \\
b\end{array}$ & $\begin{array}{c}1.90 \\
(0.06) \\
\text { cde }\end{array}$ & $\begin{array}{c}4.07 \\
(0.05) \\
q\end{array}$ & $\begin{array}{c}1.363 \\
\left(5 \times 10^{-4}\right) \\
a\end{array}$ \\
\hline & $\begin{array}{ll}\text { fter } & \text { ty } \\
\text { weeks } & \end{array}$ & $\begin{array}{c}933.8 \\
(0.32) \\
\text { cd }\end{array}$ & $\begin{array}{c}55.37 \\
(0.14) \\
c\end{array}$ & $\begin{array}{c}0.0684 \\
(0.0003) \\
\text { bc }\end{array}$ & $\begin{array}{c}136 \\
(0.82) \\
d\end{array}$ & $\begin{array}{c}1.84 \\
(0.03) \\
a b c\end{array}$ & $\begin{array}{c}3.72 \\
(0.08) \\
\mathrm{e}\end{array}$ & $\begin{array}{c}1.363 \\
\left(5 \times 10^{-4}\right) \\
a\end{array}$ \\
\hline & $\begin{array}{l}\text { fter thr } \\
\text { weeks }\end{array}$ & $\begin{array}{c}934.5 \\
(0.53) \\
d\end{array}$ & $\begin{array}{c}55.32 \\
(0.07) \\
c d\end{array}$ & $\begin{array}{c}0.0693 \\
(0.0004) \\
\text { bc }\end{array}$ & $\begin{array}{c}155 \\
(1.27) \\
\mathrm{e}\end{array}$ & $\begin{array}{c}1.80 \\
(0.04) \\
a b\end{array}$ & $\begin{array}{c}3.56 \\
(0.05) \\
d\end{array}$ & $\begin{array}{c}1.364 \\
\left(5 \times 10^{-4}\right) \\
a\end{array}$ \\
\hline & $\begin{array}{ll}\text { fter } & \text { fo } \\
\text { weeks } & \end{array}$ & $\begin{array}{c}945.7 \\
(0.47) \\
h\end{array}$ & $\begin{array}{c}55.28 \\
(0.04) \\
\text { bcd }\end{array}$ & $\begin{array}{c}0.0705 \\
(0.001) \\
c\end{array}$ & $\begin{array}{c}176 \\
(1.01) \\
g\end{array}$ & $\begin{array}{c}1.78 \\
(0.06) \\
a\end{array}$ & $\begin{array}{c}3.46 \\
(0.03) \\
\text { cd }\end{array}$ & $\begin{array}{c}1.364 \\
\left(3 \times 10^{-4}\right) \\
a\end{array}$ \\
\hline \multirow[t]{4}{*}{ PBP } & fter a wee & $\begin{array}{c}933.4 \\
(0.57) \\
\text { bc }\end{array}$ & $\begin{array}{c}55.36 \\
(0.09) \\
\text { bc }\end{array}$ & $\begin{array}{c}0.0696 \\
(0.0006) \\
\text { bc }\end{array}$ & $\begin{array}{c}134 \\
(1.13) \\
c\end{array}$ & $\begin{array}{c}1.91 \\
(0.05) \\
\text { de }\end{array}$ & $\begin{array}{c}3.92 \\
(0.06) \\
f\end{array}$ & $\begin{array}{c}1.364 \\
\left(5 \times 10^{-4}\right) \\
a\end{array}$ \\
\hline & $\begin{array}{ll}\text { fter } & \text { tV } \\
\text { weeks } & \end{array}$ & $\begin{array}{c}935.9 \\
(0.25) \\
\mathrm{e}\end{array}$ & $\begin{array}{c}55.12 \\
(0.09) \\
a b c\end{array}$ & $\begin{array}{c}0.0724 \\
(0.0006) \\
d\end{array}$ & $\begin{array}{c}161 \\
(0.56) \\
f\end{array}$ & $\begin{array}{c}1.86 \\
(0.03) \\
\text { bcd }\end{array}$ & $\begin{array}{c}3.42 \\
(0.06) \\
c\end{array}$ & $\begin{array}{c}1.365 \\
\left(3 \times 10^{-4}\right) \\
b\end{array}$ \\
\hline & $\begin{array}{l}\text { fter thr } \\
\text { weeks }\end{array}$ & $\begin{array}{c}937.2 \\
(0.27) \\
f\end{array}$ & $\begin{array}{c}55.06 \\
(0.08) \\
a b\end{array}$ & $\begin{array}{c}0.0745 \\
(0.0006) \\
\mathrm{e}\end{array}$ & $\begin{array}{c}188 \\
(0.87) \\
h\end{array}$ & $\begin{array}{c}1.83 \\
(0.03) \\
a b\end{array}$ & $\begin{array}{c}3.04 \\
(0.06) \\
b\end{array}$ & $\begin{array}{c}1.366 \\
\left(5 \times 10^{-4}\right) \\
c\end{array}$ \\
\hline & $\begin{array}{ll}\text { fter } & \text { fo } \\
\text { weeks } & \end{array}$ & $\begin{array}{c}938.9 \\
(0.44) \\
g\end{array}$ & $\begin{array}{c}55.01 \\
(0.04) \\
a\end{array}$ & $\begin{array}{c}0.0760 \\
(0.001) \\
f\end{array}$ & $\begin{array}{c}205 \\
(0.44) \\
i\end{array}$ & $\begin{array}{c}1.82 \\
(0.03) \\
a b\end{array}$ & $\begin{array}{c}2.80 \\
(0.07) \\
a\end{array}$ & $\begin{array}{c}1.367 \\
\left(3 \times 10^{-4}\right) \\
d\end{array}$ \\
\hline
\end{tabular}

${ }^{*}$ expressed as acetic acid; ${ }^{* *}$ expressed as acetaldehyde

The values with different letters in a column $(a, b, c)$ are significantly different at $P<0.05$ 
The ethanol, total $\mathrm{SO}_{2}$, and aldehyde decreased under the influence of fruit, much more intensely than in the case of simple brandy. Alcoholic concentration decreases slowly after the introduction of cherries into plum brandy, probably due to the small size of the fruit, that, can absorb ethanol through a large contact surface. The alcohol losses of the samples are due to both evaporation and changes that alcohol suffers over time. Part of the alcohol forms chemical combinations with acids and oxygen in air, forming aldehydes, ethers. The plum brandy density increases after the addition of the fruit. The increase in total acidity in acetic acid has risen significantly, the samples falling within the limits that must be respected by the consumer. The increase in acidity is due to the soluble acids in the composition of the two types of fruit and to the very slow oxidation of alcohol in acetic acid. The value of acid extract increases significantly with the use of pears and less so when using cherries. No sulphates, chlorides or impurities were identified in any of the samples. By fruit addition to brandies, the refractive index showed a slight but significant increase, more evident in the case of pears.

\section{Chromatographic analysis}

The volatile compounds responsible for the specific aroma of the alcoholic beverages were separated by gas chromatography and presented in table 3.

Table 3. The mean values of retention times (RT) and concentrations in mg / $100 \mathrm{~mL}$ absolute alcohol with SDs for all components identified in PB1 and PBM

\begin{tabular}{|c|c|c|c|c|c|}
\hline \multirow[t]{2}{*}{ No. } & \multirow{2}{*}{$\begin{array}{l}\text { CG separated } \\
\text { components }\end{array}$} & \multicolumn{2}{|c|}{ Plum brandy (PB1) } & \multicolumn{2}{|c|}{ Plum brandy and mulberry (PBM) } \\
\hline & & \begin{tabular}{|l|} 
Retention times \\
$(\mathrm{RT}(\mathrm{min}) \pm \mathrm{SD})$ \\
\end{tabular} & $\begin{array}{c}\text { Concentration } \\
(\mathrm{mg} / 100 \mathrm{~mL} \pm \mathrm{SD}\end{array}$ & $\begin{array}{l}\text { Retention times } \\
(\mathrm{RT}(\min ) \pm \mathrm{SD})\end{array}$ & $\begin{array}{c}\text { Concentration } \\
(\mathrm{mg} / 100 \mathrm{~mL} \pm \mathrm{SD}\end{array}$ \\
\hline 1 & Met & $13.725 \pm 0.012$ & 201.22 & $13.727 \pm 0.012$ & 205.5 \\
\hline 2 & Propan-1-ol & $12.127 \pm 0.010$ & $39.93 \pm 0.98 a$ & $12.127 \pm 0.010$ & $0.99 a$ \\
\hline 3 & 2-methylpropan-1-ol & $15.408 \pm 0.014$ & $103.31 \pm$ & $15.410 \pm 0.014$ & $65 a$ \\
\hline 4 & 3-methylbutan-1-ol & $20.015 \pm 0.017$ & $269.67 \pm 8.09 a$ & $20.017 \pm 0.017$ & $261.04 \pm 7.94 a$ \\
\hline 5 & Ethyl acetate & $5.076 \pm 0.007$ & $1355.04 \pm 37.94 a$ & $5.075 \pm 0.007$ & $1348.84 \pm 35.44 a$ \\
\hline 6 & $\mathrm{Bu}$ & 17.0 & $2.12 \pm 0.06 a$ & 0.015 & $.08 \mathrm{~b}$ \\
\hline 7 & & $13.928 \pm 0$ & $0.98 \pm 0.02 b$ & $13.906 \pm 0.012$ & $0.01 a$ \\
\hline 8 & Acetaldehide & $4.852 \pm 0.005$ & $12.41 \pm 0.37 b$ & $4.852 \pm 0.005$ & $11.10 \pm 0.32 a$ \\
\hline 9 & Acetal & $17.634 \pm 0.015$ & $17.54 \pm 0.45 a$ & $17.636 \pm 0.015$ & $17.10 \pm .0 .42 a$ \\
\hline
\end{tabular}

"Means followed by the same letter in a raw are not statistically different at $P<0.05$ significance level

Figure 2a presents the chromatogram of plum brandy 1 (PB1) while Figure $2 b$, the chromatogram of PBM with a quite similar pattern. 


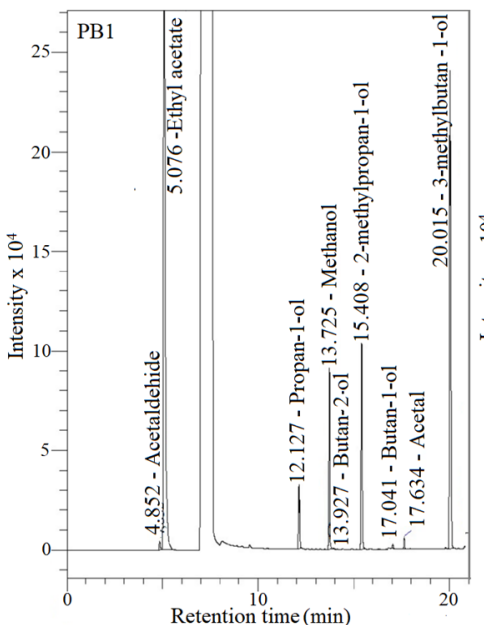

a

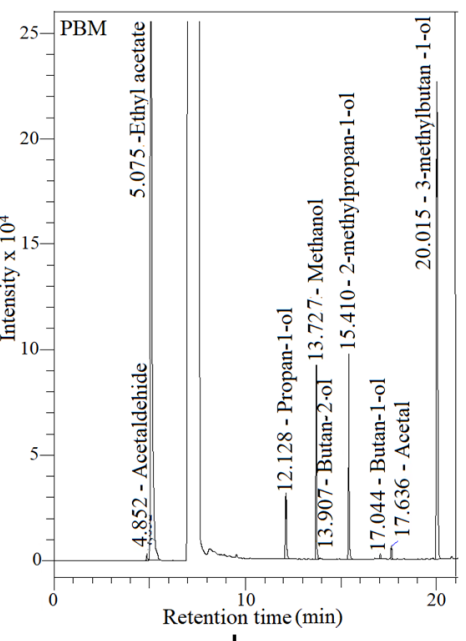

b

Figure 2. Chromatogram of plum brandy $1(\mathrm{~PB} 1, \mathrm{a})$, and plum brandy with mulberry wood (PBM, b)

In plum brandy methanol concentration is higher, when compared to other brandy alcoholic drinks due to the higher content of pectin in plums [14]. The effect of the addition of Mulberry wood in the plum brandy was a slight increase in the concentration of methanol, propanol and 1-butanol, respectively, and a decrease of the concentration of 2-methylpropanol, ethyl acetate, 2-butanol, acetaldehyde and acetal.

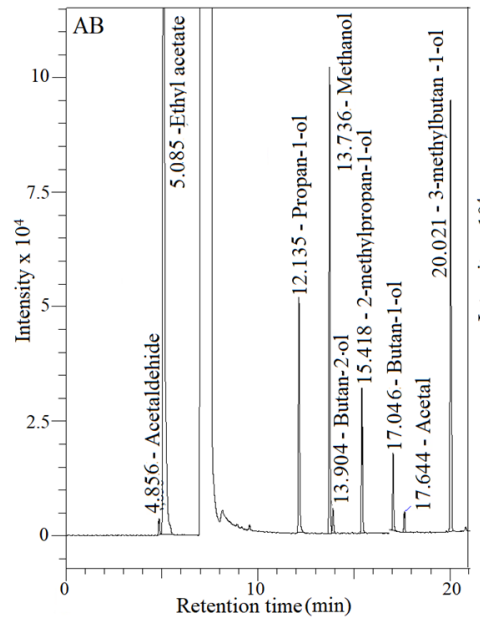

a

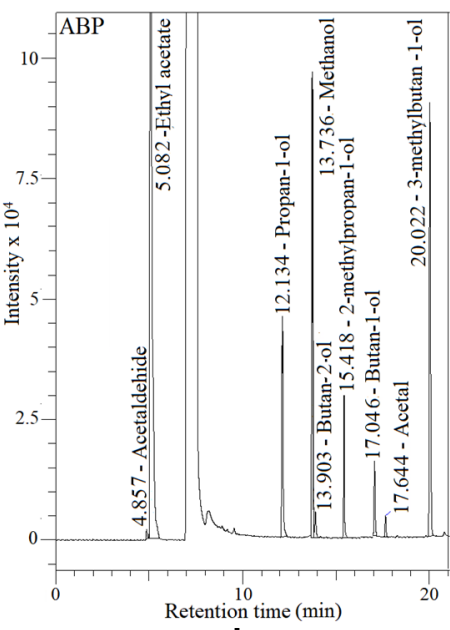

b

Figure 3. Chromatogram of apple brandy, $A B(a)$ and apple brandy with poplar wood ABP (b) 
The chromatograms of apple brandy and apple brandy maturated in the presence of poplar wood are shown in Figure $3 a$ and $b$ while the main volatile compounds present in apple brandies are shown in table 4.

Table 4. Mean retention times (RT) and concentrations in $\mathrm{mg} / 100 \mathrm{~mL}$ absolute alcohol with SDs for all components identified in the $A B$ and $A B P$ titers

\begin{tabular}{|c|c|c|c|c|c|}
\hline No & $\begin{array}{c}\text { GC Separated } \\
\text { components }\end{array}$ & \multicolumn{2}{|c|}{ Apple brandy $(\mathrm{AB})$} & \multicolumn{2}{c|}{ Apple brandy with poplar wood } \\
\cline { 3 - 6 } & & $\begin{array}{c}\text { Retention times } \\
(\mathrm{RT}(\mathrm{min}) \pm \mathrm{SD})\end{array}$ & $\begin{array}{c}\text { Concentration } \\
(\mathrm{mg} / 100 \mathrm{~mL} \pm \mathrm{SD})\end{array}$ & $\begin{array}{c}\text { Retention times } \\
\mathrm{RT}(\mathrm{min}) \pm \mathrm{SD})\end{array}$ & $\begin{array}{c}\text { Concentration } \\
(\mathrm{mg} / 100 \mathrm{~mL} \pm \mathrm{SD}\end{array}$ \\
\hline 1 & Methanol & $13.736 \pm 0.012$ & $235.04 \pm 3.66 \mathrm{a}^{*}$ & $13.736 \pm 0.012$ & $234.02 \pm 3.65 \mathrm{a}$ \\
\hline 2 & Propan-1-ol & $12.135 \pm 0.011$ & $68.31 \pm 1.58 \mathrm{a}$ & $12.127 \pm 0.010$ & $66.82 \pm 1.57 \mathrm{a}$ \\
\hline 3 & 2-methylpropan-1-ol & $15.418 \pm 0.014$ & $33.34 \pm 0.86 \mathrm{a}$ & $15.418 \pm 0.014$ & $34.26 \pm 0.89 \mathrm{a}$ \\
\hline 4 & 3-methylbutan-1-ol & $20.021 \pm 0.016$ & $107.64 \pm 2.94 \mathrm{a}$ & $20.022 \pm 0.016$ & $107.46 \pm 2.93 \mathrm{a}$ \\
\hline 5 & Ethyl acetate & $5.085 \pm 0.006$ & $992.25 \pm 26.28 \mathrm{a}$ & $5.082 \pm 0.006$ & $993.48 \pm 26.32 \mathrm{a}$ \\
\hline 6 & Butan-1-ol & $17.046 \pm 0.015$ & $17.45 \pm 0.09 \mathrm{~b}$ & $17.046 \pm 0.015$ & $17.03 \pm 0.09 \mathrm{a}$ \\
\hline 7 & Butan-2-ol & $13.904 \pm 0.011$ & $7.54 \pm 0.04 \mathrm{a}$ & $13.903 \pm 0.011$ & $8.37 \pm 0.05 \mathrm{~b}$ \\
\hline 8 & Acetaldehide & $4.856 \pm 0.005$ & $10.83 \pm 0.29 \mathrm{a}$ & $4.857 \pm 0.005$ & $9.99 \pm 0.24 \mathrm{a}$ \\
\hline 9 & Acetal & $17.644 \pm 0.014$ & $12.75 \pm 0.31 \mathrm{a}$ & $17.644 \pm 0.014$ & $13.00 \pm 0.33 \mathrm{a}$ \\
\hline
\end{tabular}

"Means followed by the same letter in a raw are not statistically different at $\mathrm{P}<0.05$ significance level

Poplar wood added in apple brandy has the effect of increasing 2methylbutanol, ethyl acetate, 2-butanol, acetal and decreasing methanol, propanol, 3-methyl-1-butanol, 1-butanol and acetaldehyde. Ethyl acetate occurred in high concentration, but still a lower value than in the case of plum brandy (PB1) or plum mulberry brandy. There is a slight increase in the propanol concentration in apple brandy when compared to the plum one. Similarly, an increase in butanol concentration is observed in the case of apple brandy. The concentration of methanol in apple brandy was higher than in the plum one due to the high content of pectin in the apple and by galacturonic acid methylation during fruit fermentation. The ethyl acetate concentrations in apple brandy are not significantly influenced by the poplar wood addition. Ester, due to the lowest organoleptic threshold, are very important in the contribution to spirit flavour, [14]. Butan-2-ol concentration in apple brandy increased by maturation in the presence of poplar wood probably under the influence of wood components.

The chromatograms of plum brandy 2, maturated in the presence of fruit (pear and cherries) are shown in Figure 4.

The main volatile compounds present in brandy samples (PBP, PBC) in comparison to plum brandy 2 subjected to maturation in the presence of fruit, are shown in table 5 . 


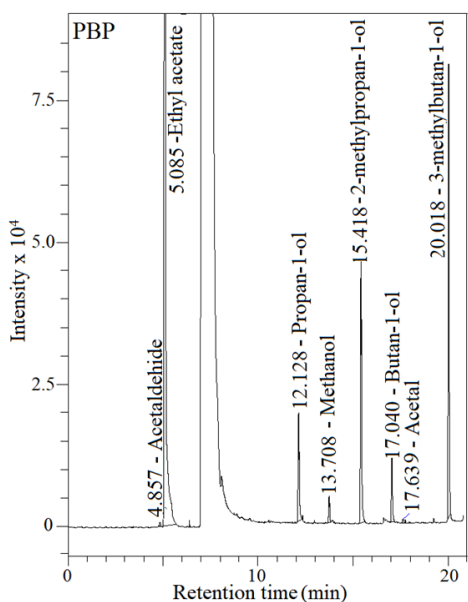

a

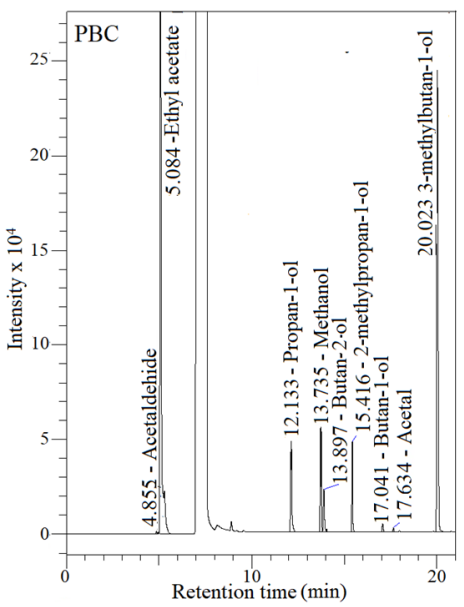

b

Figure 4. Chromatogram of plum brandy with pear PBP (a) and plum brandy with cherries PBC (b)

Table 5. Mean retention times (RT) and concentrations in $\mathrm{mg} / 100 \mathrm{~mL}$ absolute alcohol with SDs for all components identified in the PB 2 and PBP and PBC titers

\begin{tabular}{|c|c|c|c|c|c|}
\hline $\mathrm{No}$ & $\begin{array}{c}\text { CG separated } \\
\text { components }\end{array}$ & $\begin{array}{c}\text { Retention times } \\
(\mathrm{RT}(\mathrm{min}) \pm \mathrm{SD})\end{array}$ & $\begin{array}{c}\text { PB 2 } \\
(\mathrm{mg} / 100 \mathrm{~mL} \pm \mathrm{SD})\end{array}$ & $\begin{array}{c}\text { PBP } \\
(\mathrm{mg} / 100 \mathrm{~mL} \pm \mathrm{SD})\end{array}$ & $\begin{array}{c}\text { PBC } \\
(\mathrm{mg} / 100 \mathrm{~mL} \pm \mathrm{SD})\end{array}$ \\
\hline 1 & Methanol & $13.727 \pm 0.006$ & $86.62 \pm 2.12 \mathrm{~b}^{*}$ & $13.18 \pm 0.37 \mathrm{a}$ & $131.32 \pm 4.03 \mathrm{c}$ \\
\hline 2 & Propan-1-ol & $12.128 \pm 0.005$ & $20.86 \pm 0.45 \mathrm{a}$ & $32.06 \pm 0.58 \mathrm{~b}$ & $70.21 \pm 1.92 \mathrm{c}$ \\
\hline 3 & 2-methylpropan-1-ol & $15.410 \pm 0.004$ & $34.26 \pm 0.62 \mathrm{a}$ & $62.81 \pm 1 . \mathrm{c}$ & $53.47 \pm 1.42 \mathrm{~b}$ \\
\hline 4 & 3-methylbutan-1-ol & $20.017 \pm 0.005$ & $144.18 \pm 5.24 \mathrm{~b}$ & $113.48 \pm 2.99 \mathrm{a}$ & $294.15 \pm 6.52 \mathrm{c}$ \\
\hline 5 & Ethyl acetate & $5.081 \pm 0.004$ & $118.26 \pm 3.07 \mathrm{a}$ & $763.48 \pm 21.05 \mathrm{~b}$ & $1282.91 \pm 32.13 \mathrm{c}$ \\
\hline 6 & Butan-1-ol & $17.041 \pm 0.015$ & $0.79 \pm 0.02 \mathrm{a}$ & $15.18 \pm 0.45 \mathrm{c}$ & $5.22 \pm 0.15 \mathrm{~b}$ \\
\hline 7 & Butan-2-ol & $13.893 \pm 0.006$ & $0.00 \pm 0.00 \mathrm{a}$ & $0.00 \pm 0.00 \mathrm{a}$ & $32.09 \pm 0.59 \mathrm{~b}$ \\
\hline 8 & Acetaldehyde & $4.855 \pm 0.003$ & $4.34 \pm 0.34 \mathrm{c}$ & $2.81 \pm 0.08 \mathrm{a}$ & $3.46 \pm 0.14 \mathrm{~b}$ \\
\hline 9 & Acetal & $17.637 \pm 0.005$ & $14.06 \pm 0.39 \mathrm{c}$ & $2.60 \pm 0.07 \mathrm{a}$ & $6.82 \pm 0.19 \mathrm{~b}$ \\
\hline
\end{tabular}

Means followed by the same letter in a raw are not statistically different at $\mathrm{P}<0.05$ significance level

The amount of methanol decreases in the brandy containing pears and grows in cherry plum brandy because of the higher content of pectin in cherries, especially during fruit fermentation. By adding pears and cherries to plum brandy, a considerable increase of propanol and 3-methylbutanol is observed. While the concentration of 2-methylpropanol and 1-butanol increases much more in the pear-containing brandy, than in that containing cherries. 3methylbutanol and 2-methylpropanol may have both positive and negative 
effects on the flavor, increasing their concentrations giving a strong, spicy aroma and specific taste, while low concentrations can give a fruity character [17]. Non-existing 2-butanol in plum brandy and that with pear increases greatly in cherry plum brandy. In literature, it has been shown that 1-butanol and 2butanol are highly discriminating parameters of alcoholic beverages [18].

Acetal is present in very low concentrations in cherry or pear brandy, but its presence is relevant due to its contribution to the spirit flavour with unpleasant notes [19]. The acetal concentration decreases with the addition of fruit (pear and cherry) to the brandy. The content of acetaldehyde and higher alcohols are related to the ethanol content. Acetaldehyde content increases during aging due to chemical oxidation of ethanol and it may cause the formation of a larger quantity of acetal during maturation of distillates. Table 5 shows that the content of acetaldehyde decreases greatly under the influence of pears and cherries.

Ethyl acetate in plum brandy has a relatively low value, and due to the influence of the pears, it increases greatly, even more in cherry brandy [14]. Increasing the amount of ethyl acetate was due to the formation of chemical combinations of alcohol with the acids in the composition of wood, with oxygen in the air. The consequence is that ethyl acetate, due to the low organoleptic threshold, greatly influences the aroma of spirits, due to its decomposition to acetic acid and ethanol [14]. Other causes of the high levels of ethyl acetate may be the prolonged aerobic deposition of cherries or pears before introduction into the brandy, where rapid fermentation occurs, the destruction of acetic bacteria, or the corresponding separation of the fractions of the heads during distillation [14, 19].

\section{Cluster analysis}

Cluster analysis established the similarities between the brandy assortments and between the volatile components of the brandies. Figure 5 shows the formation of 2 major clusters, $\mathrm{C} 1$ and $\mathrm{C} 2$. Cluster $\mathrm{C} 1$ comprises 5 elements: the subcluster composed by brandies PB and PBW, another subcluster composed by $\mathrm{AB}$ and $\mathrm{ABP}$, and, at a higher Euclidean distance, PBC. Cluster $\mathrm{C} 2$ comprises 2 elements: PB2 and PBP. The addition of fruit (cherry or pears) significantly influences the composition of volatile compounds while the addition of mulberry wood to plum brandy or of poplar wood to apple brandy do not, taking into account that PB1 and PBM, respectively AM and $A B M$, showed a high similarity considering the volatile compounds (Euclidean distance lower than 1). 
Dendrogram

Nearest Neighbor Method,Squared Euclidean

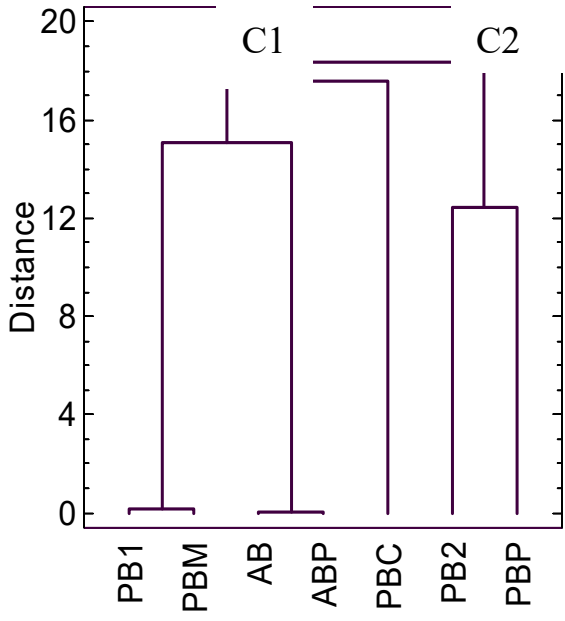

Figure 5. Cluster analysis of fruit brandies

\section{CONCLUSION}

The influence of wood and fruit addition to the plum and apple brandies on the composition of brandies during the maturation over 4 weeeks was studied. Poplar and mulberry wood have a significant influence on the plum and apple distillates, the concentrations of ethanol and aldehydes decreasing in both distillates. Due to the evaporation of the volatile substances in the brandies in which mulberry and poplar wood were added, the amount of extract increased over time. The total acidity of the samples increased due to the decrease in alcoholic strength. The alcoholic concentration of the brandy with cherries and pears decreases when compared to that without fruit, due to the evaporation, absorption into fruit mass and esterifcation with acids derived from fruit. The aldehydes concentrations of the brandy with cherries and pears also decrease compared to that without fruit due to their high chemical reactivity. The refractive indices of plum brandies with cherries and pears showed a slight increase. Chromatographic analysis showed volatile compounds with large differences in their concentrations, depending on the range of brandy, but also on the maturation conditions. The superior quality of the brandy is given by a much lower content in higher alcohols, in methyl alcohol and in aldehydes, as well as a lower acidity. Large differences in volatile compounds were found, depending on the type of brandy (plum), but also on the fruit used. 


\section{EXPERIMENTAL SECTION}

\section{Provenance of fruit brandy samples}

The fruit brandies (plum and apple) were purchased from local producers that used traditional manufacturing methods. Two fruit growing areas in Maramures County were considered: the area around Baia Mare city and the northeastern part of the county were the tradition of fruit brandy manufacturing is well-preserved. Plum brandy 1 (PB1) and apple brandy originate from the fruit growing area around Baia Mare, while plum brandy 2 was produced in Poienile de sub Munte located in the northeastern part of Maramureș County.

\section{Influence of wood and fruit on the fruit brandy physico-chemical properties}

To simulate the aging process, pieces of mulberry or poplar wood were added to the plum or apple brandy. In other experiment, fruit (pear and cherry) were added to brandy samples to assess the influence of maturation in the presence of fruit.

Mulberry wood was added to PB1: plum brandy was poured into a glass bottle containing a mulberry piece of wood, at a ratio of about 5:100 $(\mathrm{m} / \mathrm{V})$. The same procedure was carried out for apple brandy but a piece of poplar was used instead. The influence of mulberry or poplar wood on the physicochemical properties of fruit brandy was assessed by the weekly determination of density, ethanol concentration, total extract, total acidity, aldehyde content, refractive index, during a period of four weeks. The fruit influence on plum brandy was established the same way. The ratio fruit: brandy was $10: 100(\mathrm{~m} / \mathrm{V})$. We studied the changes in the physico-chemical composition of fruit brandies during the maturation process. After 4 weeks of maturation, the composition in major volatile compounds was comparatively analyzed in regards to control brandies without wood or fruit addition.

\section{Physico-chemical analysis of distillates}

The determination of the relative density of the product to be analyzed was carried out by the pycnometer method [20]. A $100 \mathrm{~mL}$ pycnometer was used and the relative density was calculated as a ratio of pycnometer mass filled with the alcoholic beverage and pycnometer mass filled with distilled water at $20^{\circ} \mathrm{C}$.

The determination of the total dry extract is carried out following the established method [20-21] by putting a certain volume $(25 \mathrm{~mL})$ of brandy into a metallic flat-bottomed cylindrical capsule of known and constant mass. The brandy was evaporated on a water bath, dried in a laboratory oven at $105{ }^{\circ} \mathrm{C}$ 
for $2 \mathrm{~h}$ and cooled in a desiccator for 30 minutes. The capsule containing the dry extract was weighed on the analytical balance and the result was expressed in $\mathrm{g} / \mathrm{L}$.

The determination of total acidity was performed following the established procedure [20]: a sample of $25 \mathrm{~mL}$ fruit brandy from which $\mathrm{CO}_{2}$ was removed was diluted with $200 \mathrm{~mL}$ of cooled boiled distillated water and titrated against $0.05 \mathrm{~N}$ hydroxide solution in the presence of phenolphthalein [20-21].

The total $\mathrm{SO}_{2}$ was measured according to the SR6182/13-2009 standard by converting the sulfites into volatile $\mathrm{SO}_{2}$ that was steam distillated into a standard solution of $I_{2}$. A redox process takes place reducing partially $I_{2}$. The residual $\mathrm{I}_{2}$ was determined by a redox titration with a standard solution of sodium thiosulphate in the presence of a starch indicator (1\% aqueous solution).

The aldehyde content was measured according to a standardized titrimetric method [22] based on the reaction of aldehydes contained in a $50 \mathrm{~mL}$ sample with $10 \mathrm{~mL}$ of a sodium bisulphite solution of known concentration $(0.05$ $\mathrm{N})$. The mixture was stirred and kept in a dark environment for 30 minutes. Then an iodine standard solution of the same concentration was added and the excess of iodine was titrated with a sodium thiosulphate solution in the presence of a starch indicator. A blank sample of $50 \mathrm{~mL}$ distilled water was treated in a similar manner and the differences in the volumes of sodium thiosulphate solution used for blank sample and brandy sample was used to calculate the aldehyde concentration in $\mathrm{mg} / \mathrm{L}$, expressed as acetaldehyde, reported to the absolute ethanol. The qualitative test for the presence or the absence of sulphates was realized with hydrochloric acid and barium chloride. Determining the refractive index was done with a Zeiss Abbe refractometer Model G.

The volatile components in fruit brandies were analyzed by gas chromatography (GC) with a flame-ionization detector (FID) by direct injection into the gas chromatograph column using the method adapted from European Union reference method for volatile compounds [23] considering the recommendations and conclusions of similar studies [16, 24-25].

The used gas chromatograph is a Shimadzu 2025 model equipped with an automatic liquid sampler and a flame ionization detector. Separation of the analytes was performed on a capillary chromatographic column of polar silica coated with polyethylene glycol (characteristics: $30 \mathrm{~m}$ length $\mathrm{x}$ $0.32 \mathrm{~mm} \times 0.25 \mu \mathrm{m}$ thickness of polyethylene glycol film). The carrier gas was nitrogen with a flow rate of $1.5 \mathrm{~mL} /$ minute. The qualitative identification of the separated compounds was based on the retention time in the column compared to values of standards. The major identified and quantified volatile compounds, besides ethanol, were: acetaldehyde, ethyl acetate, propan-1ol, methanol, butan-2-ol, 2-methylpropan-1-ol, butan-1-ol, acetal and 3methylbutan-1-ol. All the reagents were of analytical grade. Ultrapure water (Millipore system) was also used throughout all experiments. Due to a slow 
variation during the maturation process, the analysis by gas chromatography was performed only at the end of the study for the brandies with fruit and wood and for the control brandies unmodified by the addtion of fruit or wood.

\section{Statistical analysis}

All the experimental measurements were performed in triplicate and were expressed as mean $\pm S D$ (standard deviation). Statistical analysis of data was conducted with the software programs Excel and Statgraphic. To compare the values of the volatile compounds, the least significant difference was calculated by using the Statgraphic program. The same program was used to perform the analysis of data variance (ANOVA) for multiple sample comparison to determine which means are significantly different from which others. Cluster analysis was used to establish the similarity or dissimilarity between the fruit brandies by using their mean volatile composition as classification variables. Statgraphic was used to perform the cluster analyses and generate the dendrogram plot. The fruit brandies were clustered by using their mean volatile composition as classification variables. The data was standardized before clustering, to allow all characteristics contribute to a comparable extent to the discrimination process [19]. The distance measure was the Euclidean distance and the picked linkage method was average linkage. The clusters were generated with the nearest neighbor method.

\section{REFERENCES}

1. N. Pomohaci, I. Cioltean, L. Vişan, F. Rădoi,"Țuica și rachiurile naturale”, Editura Ceres, Bucuresti, 2002.

2. M. Balcerek, K. Pielech-Przybylska, U. Dziekońska-Kubczak, P. Patelski, E. Strąk, Food Technol Biotechnol, 2017, 55 (3), 333.

3. J. Mrvcic, S. Posavec, S. Karazic, D. Stanzer, A. Peša, V. Stehlik-Tomas, Croatian J Food Sci Technol, 2012, 4 (2), 102.

4. J. Tóthová, L. Žiak, J. Sádecká, Acta Chimica Slovenica, 2008, 1, 265.

5. N. Spaho, P. Dürr, S. Grba, E. Velagić-Habul, M. Blesić, J-Institute of Brewing, 2013, 119, 48.

6. V. Tesevic, N. Nikicevic, A. Jovanovic, D. Djokovic, L. Vujisic, I. Vuckov, M. Bonic, Food Technol Biotechnol, 2005, 43, 367.

7. M.D. Croitoru, E. Topor, I. Fülöp, E. Fogarasi, Acta Medica Marisiensis, 2013, 59(4), 206.

8. D. Dimitrov, T. Yoncheva, V. Haygarov, Ukranian Food J, 2016, 5, 237. 
9. Ordin nr. 368/2008 pentru aprobarea Normelor privind definirea, descrierea, prezentarea si etichetarea bauturilor traditionale romanesti, Monitorul Oficial, Partea I nr. 496 din 02/07/2008 in Romanian (Order no 368/2008 for the approval of the Norms regarding the definition, description, presentation and labeling of traditional Romanian drinks, the Official Monitor, Part I, no 496, 02/07/2008)

10. M.J. Claus, K.A. Berglund, Journal of Food Process Engineering, 2005, 28, 53.

11. D.W. Lachenmeier, E.-M. Sohnius, Food Chem Toxicol, 2008, 46, 2903.

12. P. Paiano, G. Bianchi, E. Davoli, E. Negri, R. Fanelli, E. Fattore, Food Chem, 2014, 154, 26.

13. S. Cortés, R. Rodríguez, J.M. Salgado, J.M. Domínguez, Food Control, 2011, $22,673$.

14. V. Kostik, B. Gjorgeska, B. Angelovska, I. Kovacevska, Sci J Anal Chem., 2014, 2(4), 41.

15 I. Caldeira, M.C. Climaco, R.B. de Sousa, A.P. Belchior, J Food Eng, 2006, 76, 202.

16. T.E. Coldea, C. Socaciu, Z. Moldovan, E. Mudura, Notulae Botanicae Horti Agrobotanici, 2014, 42 (2), 530.

17. F. Rodrigues, M. Caldeira, J.S. Camara, Anal Chim Acta., 2008, 609, 82.

18. D. Wencker, M. Louis, G. Nomura, M. Hasselmann, Annales des falsifications et de l'expertise chimique et toxicologique, 1981, 74, 487.

19. S. Cortés, R. Rodríguez, J.M. Salgado, J.M. Domínguez, Food Control, 2011, $22,673$.

20. OIV (International Organisation of Vine and Wine), 2014, Compendium of international methods of analysis of spirituous beverages of vitivinicultural origin, Alcoholic strength by volume - Type I methods,

http://www.oiv.int/public/medias/2629/oiv-ma-bs-01.pdf, accesed 10.03.2018

21. H. Heymann, S.E. Ebeler, Rapid methods to analyze alcoholic beverages, In Sensory and Instrumental Evaluation of Alcoholic Beverages, 1st ed.; $\mathrm{H}$. Heymann, S.E. Ebeler, Academic Press, Elsevier, Amsterdam, Holland, 2017, Chapter 5, pp. 84-104.

22. Food Safety and Standards Authority of India, Ministry of Health and Family Welfare Government of India, New Delhi, 2015, Manual of Methods for Analysis of Alcoholic Beverages; pp.15-17

23. Commission Regulation (EC) No 2870/2000 of 19 Decembrie 2000 laying down Community reference methods for the analysis of spirits drinks, 2000, Official $\mathrm{J}$. European Commun., L333/20.

24. R.R. Madrera, B.S. Valles, 2007, J. Chromatogr Sci, 2007, 45, 428.

25. R.E. Anli, N. Vural, Y. Gucer, J-Institute of Brewing, 2007; 113, 302. 